\title{
DIAGNOSTIC VALUE OF SOLUBLE TRIGGERING RECEPTOR EXPRESSED ON MYELOID CELLS IN SPONTANEOUS BACTERIAL PERITONITIS
}

\author{
SPONTAN BAKTERIYEL PERITONITIN TANISINDA STREM-1 MOLEKÜLÜNÜN TANISAL \\ DEĞERI
}

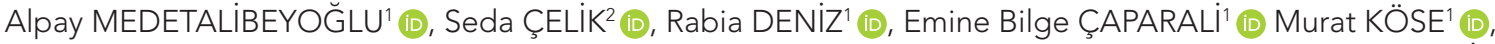

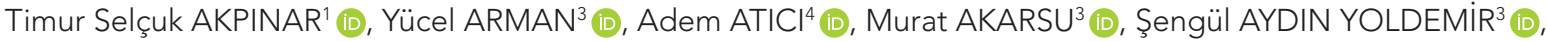
ibrahim Hakkı KÖKER ${ }^{5}$ (D), Tufan TÜKEK ${ }^{1}$ (D)

Istanbul University, Istanbul Faculty of Medicine, ${ }^{1}$ Department of Internal Medicine, ${ }^{4}$ Department of Cardiology Istanbul, Turkey

${ }^{2}$ Kafkas University, Faculty of Medicine, Biochemistry, Kars, Turkey

${ }^{3}$ Istanbul Okmeydani Training and Research Hospital, Department of Internal Medicine, Istanbul, Turkey

${ }^{5}$ Bezmialem Vakif University, Department of Gastroenterology, Istanbul, Turkey
\end{abstract}

ORCID IDs of the authors: A.M. 0000-0002-5829-9186; S.Ç. 0000-0003-2055-3537; R.D. 0000-0003-4537-894X; E.B.Ç. 0000-0001-9747-244X; M.K. 0000-0002-7487-9287; T.S.A. 0000-0002-9591-4475; Y.A. 0000-0002-9584-6644; A.A. 0000-0001-6580-7954; M.A. 0000-0002-2675-4252; S.A.Y. 0000-0003-4236-1181; I.H.K. 0000-0002-4513-6927; T.T. 0000-0002-4237-1163

Cite this article as: Medetalibeyoglu A, Celik S, Deniz R, Caparali EB, Kose M, Akpinar TS, et al. Diagnostic value of soluble triggering receptor expressed on myeloid cells in spontaneous bacterial peritonitis. J Ist Faculty Med 2020;83(4):390-6.

doi: 10.26650/IUITFD.2020.0047

\section{ABSTRACT}

Objective: The aim of this study is to investigate the role of sTREM-1 molecule in the diagnosis of spontaneous bacterial peritonitis in patients with portal type ascites.

Material and Method: We included 122 patients with portal type ascites in the study, 58 had infected ascites (peritonitis) (F/M:27/31, mean age $61.6 \pm 15.0$ years) and 64 had uninfected ascites (F/M:23/41, mean age 63.4 \pm 9.4 ). Complete blood count, albumin, and C-reactive protein (CRP) were defined in the blood samples. Additionally, neutrophil count, albumin, total protein, lactate dehydrogenase (LDH), and sTREM-1 levels were measured in the peritoneal fluid samples.

Results: There were significant differences in ascites neutrophil, serum neutrophil, CRP, ascites LDH, and ascites sTREM-1 levels between two groups. AUC values for ascites neutrophil, serum neutrophil, CRP, and sTREM-1 were 1.0 (95\% Cl 1.0-1.0), 0.676 (95\% Cl 0.580-0.771), 0.721 (95\% Cl 0.632-0.811), and 0.644 (95\% $\mathrm{Cl} 0.546-0.74)$, respectively. In females, sTREM-1 levels were positively correlated with ascites neutrophil, ascites LDH, ascites albumin, ascites total protein levels, and platelet count.

\section{ÖZET}

Amaç: Bu çalışmanın amacı portal tipte asidi olan hastalarda sTREM-1 molekülünün spontan bakteriyel peritonit tanısındaki rolünü araştırmaktır.

Gereç ve Yöntem: Çalışmaya portal tipte asiti olan 122 hasta dahil edildi, 58 hastada enfekte asit (K/E:27/31, ortalama yaş $61,6 \pm 15,0$ yıl), 64 hastada enfekte olmayan asit (K/A:23/41, ortalama yaş $63,4 \pm 9,4)$ vardı. Hastalardan başvuru sırasında alınan kan örneklerinde tam kan sayımı, albümin ve C-reaktif protein (CRP) değerleri; eşzamanlı alınan periton sıvısı örneklerinde ise albümin, total protein, laktat dehidrojenaz, (LDH) ve sTREM-1 seviyeleri ölçüldü.

Bulgular: Enfekte asitli ve enfekte olmayan asitli hastalar karşılaştırıldığında asit nötrofil, serum nötrofil, CRP, asit LDH ve asit sTREM-1 düzeylerinde anlamlı farklılıklar görüldü. Asit nötrofil, serum nötrofil, CRP ve sTREM-1 için eğrinin altında kalan alanlar (EAA) sırasıyla 1,0 (\%95 Cl 1,0-1,0), 0,676 (\%95 Cl 0,580-0,771)، 0,721 (\%95 Cl 0,632-0,811) ve 0,644 (\%95 Cl 0,546-0,74) idi. Ayrıca kadın hastalarda sTREM-1 değerleri; asit nötrofil, asit LDH, asit albümin, asit total protein değerleri ve trombosit sayısı ile pozitif korelasyon gösterdi.

Corresponding author/iletişim kurulacak yazar: dralpaymedet@gmail.com

Submitted/Başvuru: 25.04.2020 • Revision Requested/Revizyon Talebi: 09.06.2020 •

Last Revision Received/Son Revizyon: 16.06.2020 • Accepted/Kabul: 18.06.2020 • Published Online/Online Yayın: 25.09.2020

CTelif Hakkı $2020 \mathrm{~J}$ Ist Faculty Med - Makale metnine jmed.istanbul.edu.tr web sayfasından ulaşılabilir.

CCopyright 2020 by J Ist Faculty Med - Available online at jmed.istanbul.edu.tr 
Conclusion: Infection of ascites is an important complication of portal hypertension and ascites neutrophil count measurement is the traditional method used for diagnosis. STREM-1 can be an alternative marker to identify ascites infections, especially in the cases of peritonitis without an increase in neutrophil count.

Keywords: sTREM-1, spontaneous bacterial peritonitis, ascites
Sonuç: Asit enfeksiyonu portal hipertansiyonun önemli bir komplikasyonudur ve geleneksel tanı metodu asit nötrofil sayısı ölçümüdür. sTREM-1, özellikle nötrofil sayısında artış olmayan peritonit vakalarında, asit enfeksiyonlarını tanımlamak için alternatif bir belirteç olabilir.

Anahtar Kelimeler: sTREM-1, spontan bakteriyel peritonit, asit

\section{INTRODUCTION}

One of the most common complications in cirrhosis with ascites is spontaneous bacterial peritonitis $(\mathrm{SBP})(1,2)$. With early diagnosis and advanced treatment options, mortality rates of SBP have been decreased from $90 \%$ to approximately $20 \%$ (3). SBP is a serious problem for both outpatients and hospitalized patients with ascites, and the primary diagnostic tool is paracentesis (1, $4,5)$. Although patients with SBP may have symptoms related to peritonitis, systemic inflammation, impaired liver and kidney functions, shock, and gastrointestinal hemorrhage; some of the patients with SBP might be asymptomatic and misdiagnosed especially in outpatient clinics (4-6).

Triggering receptor expressed on myeloid cells-1 (TREM1) is a membrane molecule in the immunoglobulin super family. It is expressed on the surface of neutrophils and monocytes with the stimulation of bacteria and fungi. In addition to neutrophils and monocytes, it is found on dendritic cells, natural killer cells, T, and B lymphocytes as well as respiratory epithelial cells and hepatic endothelial cells. After encountering infectious agents, membrane-bound TREM-1 is upregulated. Subsequently, the soluble form of this molecule (sTREM-1) is released into body fluids such as plasma, bronchoalveolar fluid, pleural fluid, peritoneal fluid, and cerebrospinal fluid (7-12). Owing to that, sTREM-1 was thought to be used as a marker especially in bacterial infections; increased levels have been shown in sepsis, pneumonia, exacerbation of chronic obstructive pulmonary disease, secondary peritonitis and bacterial meningitis, so far (13-15). Although some studies suggested that sTREM-1 levels show no increase in uninfectious situations such as vasculitis, psoriasis, and ulcerative colitis (16), it has also been related with inflammatory and autoimmune diseases, like pancreatitis, gout, peptic ulcer, systemic lupus erythematosus in recent time $(11,12,17)$.

In the present study, the ascites STREM-1 levels were measured to identify the role of the STREM-1 molecule in the diagnosis of SBP in patients with portal type ascites and compare it with the conventional diagnostic tool of spontaneous bacterial peritonitis, ascites neutrophil count. We also aimed to determine the sensitivity and specificity of sTREM-1 in the diagnosis of SBP.

\section{MATERIAL AND METHOD}

\section{Study design and patients}

We designed this study as a cross-sectional study involving consecutive patients admitted with ascites, between September 2014 and January 2016. Only patients whose ascites were drained for the diagnostic produce with suspected peritonitis and were found to be portal type (serum acid-albumin gradient 21.1 ) were included (18). The patients who are diagnosed with a non-portal type of ascites, any malignant neoplasm, or those using antibiotics, immunosuppressive therapy, or chemotherapeutic were excluded. Overall, 122 patients were included in the study, and 58 patients with an ascites neutrophil count greater than $250 \times 10^{3} / \mathrm{mm}^{3}$ were identified as having infected ascites (19), 64 patients with an ascites neutrophil count less than $250 \times 10^{3} / \mathrm{mm}^{3}$ were defined as having uninfected ascites (Figure 1). Ethical approval was obtained from the Institutional Ethics Review Board with the number of 2014 926/955, and all participants gave informed consent.

\section{Sample and data collection}

Data on demographic, clinical, and laboratory characteristics were recorded and both ascites and blood samples were collected. Ascites samples were collected before

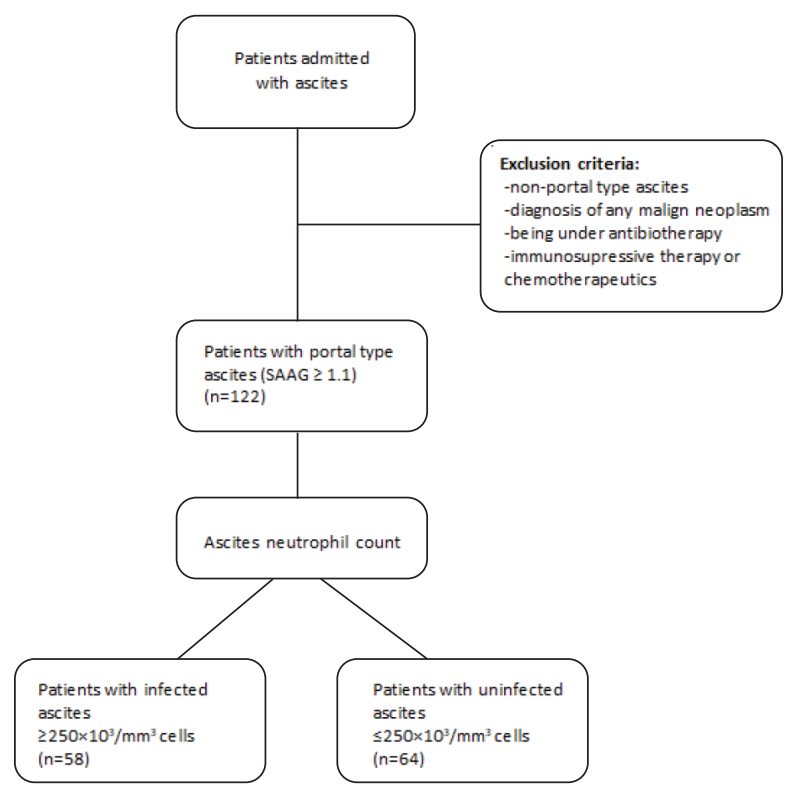

Figure 1: STARD diagram for study design. 
any intervention via the insertion of a sterile needle into the left lower quadrant of the abdomen which is the opposite of McBurney point as in the classical paracentesis procedure to determine cell count and biochemical parameters (albumin, total protein, LDH, and STREM-1). Venous blood samples were taken into both an EDTA anticoagulated tube for the complete blood count and a dry tube for the serum biochemical parameters (albumin and C-reactive protein). Complete blood count and plasma biochemistry analysis were done by our central biochemistry laboratory based on routine protocols. To determine the cell count and collect the supernatant, ascites samples were centrifuged at $1500 \mathrm{rpm}$ for 10 minutes at $+4^{\circ} \mathrm{C}$, and the supernatant was kept at $-80^{\circ} \mathrm{C}$. The concentrations of sTREM-1 in ascites fluids were measured by following the manufacturer's instructions with commercial sandwich enzyme-linked immunosorbent assays (ELISA) in 96-well plates which have an assay range of 3 to 900 $\mathrm{ng} / \mathrm{L}$ and sensitivity of $1.51 \mathrm{ng} / \mathrm{L}$.

\section{Statistical analysis}

Distribution of the data was analyzed and continuous variables were presented as mean \pm standard deviation (SD).
The differences between groups and subgroups were analyzed by parametric Student's t-test and non-parametric Mann-Whitney $U$ test as applicable. Correlation of sTREM-1 values with other diagnostic tests were analyzed by Spearman or Pearson correlation coefficients. To evaluate the diagnostic performance of sTREM-1, receiver operating characteristics (ROC) with corresponding areas under the curve (AUCs) were calculated. Since peritonitis is diagnosed by the presence of more than $250 \times 10^{3} / \mathrm{mm}^{3}$ neutrophils in ascites fluid, it was accepted as the gold standard when compared to other diagnostic tests and sTREM-1.

$P$ values less than 0.05 were considered statistically significant. Statistical analyses were performed by using SPSS 21.0.0.0 (SPSS Inc.), Graphpad Prism v5. (GraphPad, Software Inc.), and MedCalc v16.8.4 (MedCalc Software).

\section{RESULTS}

The characteristics of patients with infected ascites and uninfected ascites are presented in Table 1. Significant differences between two groups were seen on ascites neutrophil, serum neutrophil, CRP, ascites LDH, and asci-

Table 1: The patient characteristics for the patients with infected ascites and uninfected ascites

\begin{tabular}{|c|c|c|c|c|c|c|}
\hline \multirow[b]{2}{*}{$\begin{array}{l}\text { Group, } \\
\text { (number) }\end{array}$} & \multicolumn{3}{|c|}{ Patients with uninfected ascites ( $n$ ) } & \multicolumn{3}{|c|}{ Patients with infected ascites ( $n$ ) } \\
\hline & Female (23) & Male (41) & Total (64) & Female (27) & Male (31) & Total (58) \\
\hline $\begin{array}{l}\text { Ascites } \\
\text { albumin (g/dL) }\end{array}$ & $1.16 \pm 1.0$ & $1.05 \pm 0.8$ & $1.09 \pm 0.9$ & $1.20 \pm 1.0$ & $1.31 \pm 0.8$ & $1.26 \pm 0.9$ \\
\hline $\begin{array}{l}\text { Ascites total } \\
\text { protein }(\mathrm{g} / \mathrm{dL})\end{array}$ & $2.07 \pm 1.4$ & $2.07 \pm 1.3$ & $2.07 \pm 1.3$ & $2.48 \pm 1.7$ & $2.41 \pm 1.1$ & $2.44 \pm 1.4$ \\
\hline $\begin{array}{l}\text { Ascites } \\
\text { LDH (u/L) }\end{array}$ & $88.04 \pm 69.7$ & $117.95 \pm 103.9$ & $107.20 \pm 93.6$ & $328.00 \pm 828.5$ & $172.10 \pm 160.5$ & $244.67 \pm 576.9$ \\
\hline $\begin{array}{l}\text { Ascites } \\
\text { neutrophil } \\
\left(/ \mathrm{mm}^{3}\right)\end{array}$ & $108.70 \pm 65.1$ & $124.66 \pm 56.6$ & $118.92 \pm 59.8$ & $1877.78 \pm 2732.0$ & $2608.06 \pm 6807.3$ & $2268.10 \pm 5284.4$ \\
\hline sTREM-1 (ng/L) & $381.79 \pm 174.6$ & $380.38 \pm 190.7$ & $380.89 \pm 183.7$ & $513.78 \pm 198.5$ & $423.81 \pm 208.1$ & $465.69 \pm 206.9$ \\
\hline $\begin{array}{l}\text { Serum albumin } \\
(\mathrm{g} / \mathrm{dL})\end{array}$ & $3.23 \pm 0.7$ & $2.74 \pm 0.6$ & $2.91 \pm 0.7$ & $2.87 \pm 0.7$ & $2.95 \pm 0.4$ & $2.91 \pm 0.6$ \\
\hline $\begin{array}{l}\text { Serum CRP } \\
(\mathrm{mg} / \mathrm{L})\end{array}$ & $26.93 \pm 30.5$ & $38.39 \pm 44.6$ & $34.27 \pm 40.2$ & $70.35 \pm 67.5$ & $92.89 \pm 87.2$ & $82.40 \pm 78.8$ \\
\hline $\begin{array}{l}\text { Serum } \\
\text { neutrophil } \\
\left(/ \mathrm{mm}^{3}\right)\end{array}$ & $4976.09 \pm 7028.2$ & $5634.15 \pm 4095.4$ & $5397.66 \pm 5291.3$ & $7267.41 \pm 6112.5$ & $8467.74 \pm 8764.3$ & $7908.97 \pm 7604.5$ \\
\hline $\begin{array}{l}\text { Hemoglobin } \\
\text { (g/dL) }\end{array}$ & $9.90 \pm 1.8$ & $9.86 \pm 1.62$ & $9.87 \pm 1.7$ & $9.80 \pm 1.9$ & $10.39 \pm 1.9$ & $10.11 \pm 1.9$ \\
\hline $\begin{array}{l}\text { Platelets } \\
(/ \mu \mathrm{L})\end{array}$ & $143000 \pm 160100$ & $168500 \pm 138925$ & $159000 \pm 146000$ & $149000 \pm 149300$ & $149500 \pm 100100$ & $149000 \pm 124000$ \\
\hline MPV (fL) & $8.63 \pm 1.3$ & $8.96 \pm 1.1$ & $8.84 \pm 1.2$ & $8.75 \pm 1.3$ & $8.58 \pm 1.3$ & $8.66 \pm 1.3$ \\
\hline MELD & $11.70 \pm 5.6$ & $11.20 \pm 5.1$ & $11.38 \pm 5.3$ & $11.56 \pm 4.9$ & $12.26 \pm 4.0$ & $11.93 \pm 4.4$ \\
\hline
\end{tabular}


tes sTREM-1 levels $(p<0.0001,0.001,<0.0001,0.002$, and 0.006 , respectively).

Subgroups analysis for gender showed significant differences in the comparison of male patients with infected ascites and uninfected ascites for the ascites neutrophil, serum neutrophil, ascites LDH, and CRP ( $p<0.0001$, $0.02,0.02$, and 0.01 , respectively) while the difference in sTREM-1 values was insignificant $(p=0.29)$. In females with infected ascites and uninfected ascites, there was a significant difference in the ascites neutrophil, CRP, ascites $L D H$, serum neutrophil, and sTREM ( $p<0.0001,0.006$, $0.015,0.006$, and 0.007 , respectively).

Etiology of cirrhosis was found in patients as; HBV-related $31.1 \%$, cryptogenic $20.5 \%$, HCV-related $23.0 \%$, alcoholic

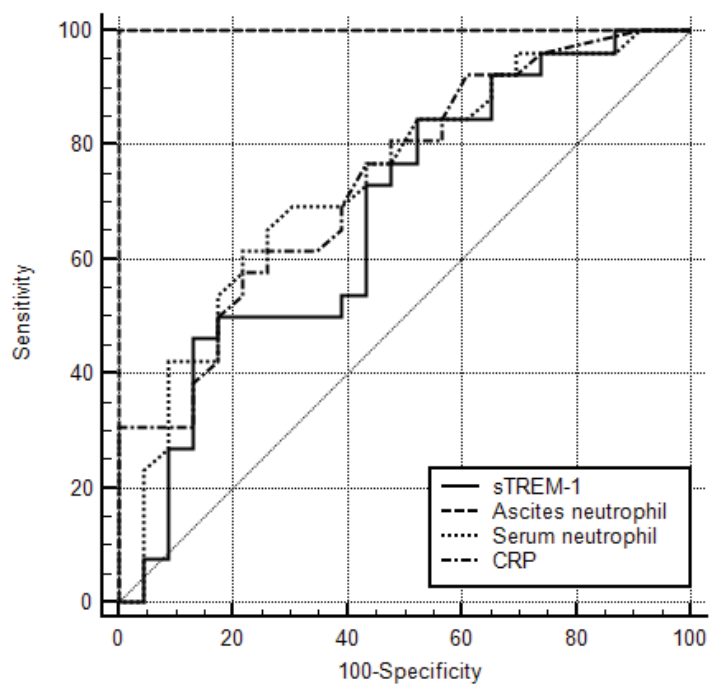

A
$11.5 \%$, autoimmune $4.9 \%$, and other $9.0 \%$ (including; Caroli's disease, portal vein thrombosis, non-alcoholic steatohepatitis, and hepatic fibrosis). There were no significant differences in the causes of cirrhosis on subgroup analysis for neither gender nor ascites infection status, however, all patients with autoimmune causes were female $(n=6)$.

The predictive power of sTREM-1, ascites neutrophil, serum neutrophil, and CRP in the diagnosis of ascites infection is demonstrated as the area under the receiver operating characteristic curve (AUC) and given in Figure 2.

In ROC analysis to differentiate patients with infected ascites and uninfected ascites, AUC values for ascites neutrophil (gold standard criteria), serum neutrophil, CRP, and sTREM-1 were $1.0(95 \% \mathrm{Cl} 1.0-1.0), 0.676(95 \% \mathrm{Cl}$

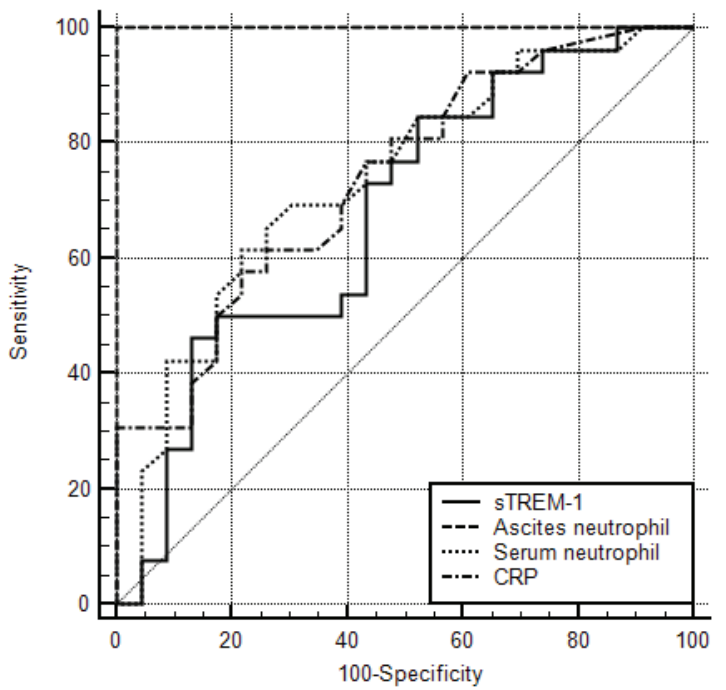

B

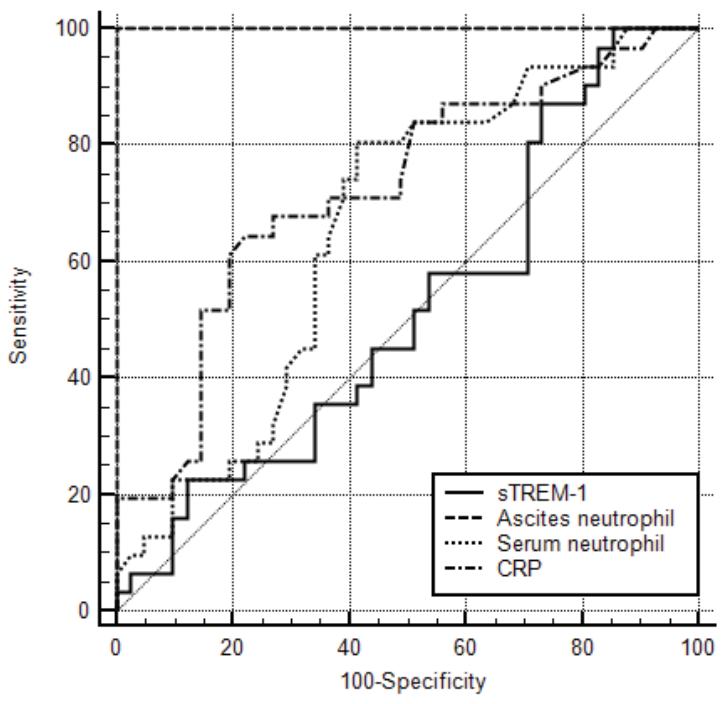

C

Figure 2A-C: ROC curve in the diagnosis of patients with infected ascites versus uninfected ascites A: for overall groups, B: female patients, C: and male patients. 
Table 2: Spesificity, sensitivity, positive predictive value, and negative predictive value of different markers in the diagnosis of patients with infected ascites versus uninfected ascites

\begin{tabular}{|c|c|c|c|c|c|c|c|c|}
\hline Variable & Threshold & $\begin{array}{l}\text { Sensitivity } \\
(95 \% \mathrm{Cl}) \%\end{array}$ & $\begin{array}{l}\text { Spesificity } \\
(95 \% \text { Cl)\% }\end{array}$ & $\begin{array}{l}\text { Positive } \\
\text { predictive } \\
\text { value }\end{array}$ & $\begin{array}{l}\text { Negative } \\
\text { predictive } \\
\text { value }\end{array}$ & $\begin{array}{l}\text { Positive Like- } \\
\text { lihood Ratio } \\
(95 \% \mathrm{Cl})\end{array}$ & $P$ & $\begin{array}{c}\text { AUC } \\
(95 \% \text { CI)\% }\end{array}$ \\
\hline $\begin{array}{l}\text { sTREM-1 } \\
\text { (ng/L) }\end{array}$ & 452 & $\begin{array}{c}0.48 \\
(0.35-0.62)\end{array}$ & $\begin{array}{c}0.77 \\
(0.64-0.86)\end{array}$ & 0.65 & 0.62 & $\begin{array}{c}2.06 \\
(1.2-3.5)\end{array}$ & 0.004 & $\begin{array}{c}0.644 \\
(0.556-0.744)\end{array}$ \\
\hline $\begin{array}{l}\text { Serum CRP } \\
(\mathrm{mg} / \mathrm{L})\end{array}$ & 47 & $\begin{array}{c}0.59 \\
(0.45-0.71)\end{array}$ & $\begin{array}{c}0.77 \\
(0.64-0.86)\end{array}$ & 0.69 & 0.67 & $\begin{array}{c}2.5 \\
(1.5-4.1)\end{array}$ & $<0.0001$ & $\begin{array}{c}0.721 \\
(0.632-0.811)\end{array}$ \\
\hline $\begin{array}{l}\text { Serum } \\
\text { neutrophil } \\
\left(\times 10^{3} / \mathrm{mm}^{3}\right)\end{array}$ & 4300 & $\begin{array}{c}0.72 \\
(0.59-0.83)\end{array}$ & $\begin{array}{c}0.63 \\
(0.50-0.74)\end{array}$ & 0.64 & 0.71 & $\begin{array}{c}1.93 \\
(1.4-2.8)\end{array}$ & 0.0003 & $\begin{array}{c}0.676 \\
(0.580-0.771)\end{array}$ \\
\hline $\begin{array}{l}\text { Ascites } \\
\text { neutrophil } \\
\left(\times 10^{3} / \mathrm{mm}^{3}\right)\end{array}$ & 250 & 1.0 & 1.0 & 1.0 & 1.0 & $\begin{array}{c}3.76 \\
(2.5-5.7)\end{array}$ & $<0.0001$ & $\begin{array}{c}1.00 \\
(1.0-1.0)\end{array}$ \\
\hline
\end{tabular}

$0.580-0.771), 0.721$ (95\% Cl 0.632-0.811), and 0.644 (95\% Cl 0.546-0.744), respectively (Figure 2).

Additionally, subanalysis for ascites neutrophil, serum neutrophil, CRP, and sTREM-1 values according to gender were performed by determining AUC. In male patients results were $1.0(95 \% \mathrm{Cl} 1.0-1.0), 0.660(95 \% \mathrm{Cl}$ $0.533-0.787), 0.725(95 \% \mathrm{Cl} 0.606-0.844), 0.574(95 \% \mathrm{Cl}$ $0.440-0.707)$, and in female patients were $1.0(95 \% \mathrm{Cl}$ $1.0-1.0), 0.727$ (95\% Cl 0.585-0.869), 0.726 (95\% Cl 0.587$0.865), 0.721$ (95\% Cl 0.575-0.868), respectively (Figure 2).

Sensitivity, specificity, positive predictive value, negative predictive value, and AUC of variables are given in Table 2.

Although it was not strong, a positive correlation was found between sTREM-1 and ascites neutrophil $(r=0.24$, $\mathrm{p}=0.009$ ). In female patients, sTREM-1 was found positively correlated with ascites neutrophil, ascites LDH, ascites albumin, ascites total protein, and platelet count $(r=0.37, p=0.007 ; r=0.27, p=0.05 ; r=0.272, p=0.06 ; r=0.30$, $p=0.04$; and $r=0.30, p=0.03$, respectively), while there was no positive correlation between STREM-1 and any parameters in male patients.

\section{DISCUSSION}

Triggering receptor expressed on myeloid cells-1 (TREM1) and its soluble form STREM-1 have increasing popularity in last years, notably for their potential role as a biomarker in the diagnosis of bacterial infections, as well as some inflammatory diseases. Studies of sTREM-1 molecule mainly focused on sepsis $(7,14,15,20,21)$. Although there is a study investigating the effect of sTREM-1 molecule in diagnosing secondary peritonitis, (13), this is the first study in the literature investigating the role of sTREM-1 molecule for the diagnosis of SBP.
Ascites neutrophil count is accepted as the conventional diagnostic marker for the diagnosis of SBP, mainly due to the lower positive culture rates in ascites infections and relative difficulties of performing culture related to technique (22-24). However, these may cause misdiagnosis of SBP cases in which neutrophil count does not increase (25). Therefore, alternative markers may be required.

Similar to the present study, same parameters were investigated as a marker determining the infection in previous studies, but most of the data were obtained from studies focused on sepsis. Nevertheless, our results are consistent with the outcomes of those studies. For example, Barati et al. found AUC values of CRP, serum neutrophil count, and STREM-1 for the diagnosis of infection in SIRS as $0.66(95 \% \mathrm{Cl} 0.54-0.77)(p=0.00), 0.59$ (95\% Cl 0.47-0.70) ( $p=0.14)$, and 0.65 (95\% Cl 0.53-0.76) $(p=0.00)$, respectively (7). The only study investigating secondary peritonitis found the AUC for STREM-1 as 0.76 (95\% Cl 0.63-0.90) (12).

In previous studies, various sensitivity and specificity values have been noted related to the sTREM-1. For example, Bayram et al. (14) found that the sensitivity and specificity of sTREM-1 molecule for sepsis were $81.8 \%$ and $73.2 \%$, respectively. Moreover, Determann et al. (13) suggested a cut-off value of $160 \mathrm{pg} / \mathrm{ml}$ for sTREM-1 in secondary peritonitis; which is quite low compared to a cut-off value of $452 \mathrm{pg} / \mathrm{ml}$ that we found for SBP with $88 \%$ sensitivity (95\% Cl 0.73-0.95) and 67\% specificity (95\% Cl 0.51-0.80). Their positive predictive value was moderate at $0.70(95 \%$ $\mathrm{Cl} 0.55-0.82)$, but the negative predictive value was high at 0.86 (95\% $\mathrm{Cl} 0.69-0.94)$. In addition, their positive likelihood ratio (LR+) was $2.63(95 \% \mathrm{Cl} 1.65-4.19)$ and the negative likelihood ratio (LR-) was 0.19 (0.08-0.47).

In the study of Determann et al. (26), sTREM-1 use was suggested to be better than CRP in identifying infection. 
In favor of this, Gibot et al. (9) found that STREM-1 is even more accurate than any laboratory values or clinical findings detecting the presence of bacterial or fungal pneumonia (LR+, 10.38; sensitivity $98 \%$; specificity $90 \%$ ). On the contrary Latour-Perez et al. (18) suggested that STREM-1 has a poor distinctive power to detect infection in critically ill patients with SIRS and does not have an additional diagnostic value to the diagnostic value provided by other commonly used clinical tests. Our results, on the other hand, showed a similar specificity, positive predictive value, and negative predictive value, as well as little lower sensitivity, AUC, and LR for sTREM-1 compared to CRP. Due to the fact that unless the causative pathogen is shown, no single predictor can not be the perfect diagnostic tool for the infections or SBP, sTREM-1 may be at least a contributor for the evaluation of the patient with the suspicion of SBP.

Another notable finding in our study is that sTREM-1 has been shown to be more specific in females compared to males. This has not been discussed in previous studies for sTREM-1. But the cause of this difference is not clear.

The study has some limitations. First, although we planned to evaluate the role of STREM-1 in the diagnosis of SBP, we made the diagnosis based on the number of ascites neutrophil count, as it is still the gold standard. However, some SBP cases may be missed because the number of ascites neutrophils does not increase. Therefore, future studies are necessary in this regard. Second, the study population is relatively small to show possible significant differences in subgroup analysis. Both ROC and correlation analysis suggested that SBP has a more significant relationship with increased sTREM-1 levels in female patients. However, there is no known gender or hormone-based difference for the production and release of STREM-1 on literature. These results we found may be due to small subgroup sizes. Therefore, further research is needed with larger populations to determine the role of the sTREM-1 molecule in the diagnosis and prognosis of peritonitis and clarify this possible gender effect.

In conclusion, infection of ascites is an important complication of portal hypertension, and the neutrophil count in ascites fluid is the traditional and widely used tool for the diagnosis. Recently, it has been shown that sTREM-1 molecule released from myeloid cells that encounter bacteria, can detect infections, similar to the well-known infection marker CRP. Therefore, sTREM-1 could be an alternative marker to identify ascites infections, especially in cases of peritonitis without an increase in the neutrophil count.

Ethics Committee Approval: This study was approved by the Ethical Committee of the Istanbul University, Istanbul Faculty of Medicine (Decision no: 2014-926/955).
Informed Consent: Written consent was obtained from the participants.

Peer Review: Externally peer-reviewed.

Author Contributions: Conception/Design of Study- A.M., S.Ç., R.D., M.K., M.A.; Data Acquisition- A.A., Ş.A.Y., I.H.K., E.B.Ç.; Data Analysis/Interpretation- T.T., Y.A., T.S.A., E.B.Ç.; Drafting Manuscript- A.M., S.Ç., R.D., A.A., Ş.A.Y.; Critical Revision of Manuscript- T.T., Y.A., T.S.A., I.H.K., M.K., M.A.; Final Approval and Accountability- A.M., S.Ç., R.D., E.B.Ç., M.K., T.S.A., Y.A., A.A., M.A., S..A.Y., I.H.T., T.T.; Technical or Material SupportA.M., S.Ç., R.D., M.K., E.B.Ç.; Supervision- T.T., Y.A.

Conflict of Interest: Authors declared no conflict of interest.

Financial Disclosure: This study was supported by the Istanbul University Scientific Research Projects Fund (BAP). (Project Number: 46543).

Etik Komite Onayı: Bu çalışma için etik komite onayı İstanbul Üniversitesi, İstanbul Tıp Fakültesi Etik Kurulu'ndan alınmıştır (Karar no: 2014-926/955).

Bilgilendirilmiş Onam: Katılımcılardan bilgilendirilmiş onam alınmıştır.

Hakem Değerlendirmesi: Dış bağımsız.

Yazar Katkıları: Çalışma Konsepti/Tasarım- A.M., S.Ç., R.D., M.K., M.A.; Veri Toplama- A.A., Ş.A.Y., I.H.K., E.B.Ç.; Veri Analizi/Yorumlama- T.T., Y.A., T.S.A., E.B.Ç.; Yazı Taslağı- A.M., S.Ç., R.D., A.A., Ş.A.Y.; iç̧eriğin Eleştirel İncelemesi- T.T., Y.A., T.S.A., I.H.K., M.K., M.A.; Son Onay ve Sorumluluk- A.M., S.Ç., R.D., E.B.Ç., M.K., T.S.A., Y.A., A.A., M.A., Ş.A.Y., I.H.T., T.T.; Malzeme ve Teknik Destek- A.M., S.Ç., R.D., M.K., E.B.Ç.; Süpervizyon- T.T., Y.A.

Çıkar Çatışması: Yazarlar çıkar çatışması beyan etmemişlerdir.

Finansal Destek: Bu çalışma İstanbul Üniversitesi Bilimsel Araştırma Projeleri Fonu (BAP) tarafından desteklenmiştir. (Proje Numarası: 46543).

\section{REFERENCES}

1. Rimola A, Garcia-Tsao G, Navasa M, Piddock LJ, Planas $\mathrm{R}$, Bernard B, et al. Diagnosis, treatment and prophylaxis of spontaneous bacterial peritonitis: a consensus document. International Ascites Club. J Hepatol 2000;32(1):142-53. [CrossRef]

2. Rostkowska KA, Szymanek-Pasternak A, Simon KA. Spontaneous bacterial peritonitis - therapeutic challenges in the era of increasing drug resistance of bacteria. Clin Exp Hepatol 2018;4(4):224-31. [CrossRef]

3. Garcia-Tsao G. Current management of the complications of cirrhosis and portal hypertension: variceal hemorrhage, ascites, and spontaneous bacterial peritonitis. Gastroenterology 2001;120(3):726-48. [CrossRef]

4. European Association for the Study of the Liver. EASL Clinical Practice Guidelines on the management of ascites, spontaneous bacterial peritonitis, and hepatorenal syndrome in cirrhosis. J Hepatol 2010;53(3):397-417. [CrossRef] 
5. Nousbaum JB, Cadranel JF, Nahon P, Khac EN, Moreau $R$, Thévenot $T$, et al. Diagnostic accuracy of the Multistix 8 SG reagent strip in diagnosis of spontaneous bacterial peritonitis. Hepatology 2007;45(5):1275-81. [CrossRef]

6. Evans LT, Kim WR, Poterucha JJ, Kamath PS. Spontaneous bacterial peritonitis in asymptomatic outpatients with cirrhotic ascites. Hepatology 2003;37(4):897-901. [CrossRef]

7. Barati M, Bashar FR, Shahrami R, Zadeh MH, Taher MT, Nojomi M. Soluble triggering receptor expressed on myeloid cells 1 and the diagnosis of sepsis. J Crit Care 2010;25(2):362.e1-6. [CrossRef]

8. Bouchon A, Dietrich J, Colonna M. Cutting edge: inflammatory responses can be triggered by TREM-1, a novel receptor expressed on neutrophils and monocytes. J Immunol 2000;164(10):4991-5. [CrossRef]

9. Gibot S, Cravoisy A, Levy B, Bene MC, Faure G, Bollaert PE. Soluble triggering receptor expressed on myeloid cells and the diagnosis of pneumonia. N Engl J Med 2004;350(5):4518. [CrossRef]

10. Sun $X G, M a Q$, Jing G, Wang GQ, Hao XD, Wang L. Increased levels of soluble triggering receptor expressed on myeloid cells-1 in cerebrospinal fluid of subarachnoid hemorrhage patients. J Clin Neurosci 2017;35:139-43. [CrossRef]

11. Ford JW, McVicar DW. TREM and TREM-like receptors in inflammation and disease. Curr Opin Immunol 2009;21(1):38-46. [CrossRef]

12. Pandupuspitasari NS, Khan FA, Huang CJ, Chen X, Zhang S. Novel Attributions of TREMs in Immunity. Curr Issues Mol Biol 2016;20:47-54. [CrossRef]

13. Determann RM, van Till JW, van Ruler O, van Veen SQ, Schultz MJ, Boermeester MA. sTREM-1 is a potential useful biomarker for exclusion of ongoing infection in patients with secondary peritonitis. Cytokine 2009;46(1):36-42. [CrossRef]

14. Bayram $H$, Tunger $O$, Civi $M$, Yuceyar MH, Ulman $C$, Dinc $H$, et al. Diagnostic and prognostic value of procalcitonin and sTREM-1 levels in sepsis. Turk J Med Sci 2015;45/3):578-86. [CrossRef]

15. Brenner T, Uhle F, Fleming T, Wieland M, Schmoch T, Schmitt $F$, et al. Soluble TREM-1 as a diagnostic and prognostic biomarker in patients with septic shock: an observational clinical study. Biomarkers 2017;22(1):63-9. [CrossRef]
16. Bouchon A, Facchetti F, Weigand MA, Colonna M. TREM-1 amplifies inflammation and is a crucial mediator of septic shock. Nature 2001;410(6832):1103-7. [CrossRef]

17. Bassyouni IH, Fawzi S, Gheita TA, Bassyouni RH, Nasr AS, El Bakry SA, et al. Clinical association of a soluble triggering receptor expressed on myeloid cells-1 (sTREM-1) in patients with systemic lupus erythematosus. Immunol Invest 2017;46(1):38-47. [CrossRef]

18. Chubb SP, Williams RA. Biochemical Analysis of Pleural Fluid and Ascites. Clinical Biochemist Reviews 2018;39(2):39-50.

19. Velkey B, Vitális E, Vitális Z. Spontán bakteriális peritonitis [Spontaneous bacterial peritonitis]. Orvosi Hetilap 2017;158(2):50-7. [CrossRef]

20. Latour-Perez J, Alcala-Lopez A, Garcia-Garcia MA, Sánchez-Hernández JF, et al. Diagnostic accuracy of sTREM-1 to identify infection in critically ill patients with systemic inflammatory response syndrome. Clin Biochem 2010;43(9):720-4. [CrossRef]

21. Charles PE, Noel R, Massin F, Guy J, Bollaert PE, Quenot $J$, et al. Significance of soluble triggering receptor expressed on myeloid cells-1 elevation in patients admitted to the intensive care unit with sepsis. BMC Infect Dis 2016;16(1):559. [CrossRef]

22. Al-Ghamdi H, Al-Harbi N, Mokhtar $H$, Daffallah $M$, Memon $Y$, Aljumah $A A$, et al. Changes in the patterns and microbiology of spontaneous bacterial peritonitis: analysis of 200 cirrhotic patients. Acta Gastroenterol Belg 2019;82(2):261-6.

23. Bal CK, Bhatia V, Daman R. Predictors of fifty days in-hospital mortality in patients with culture negative neutrocytic ascites. BMC Gastroenterol 2017;17(1):64. [CrossRef]

24. Sajjad M, Khan ZA, Khan MS. Ascitic Fluid Culture in Cirrhotic Patients with Spontaneous Bacterial Peritonitis. J Coll Physicians Surg Pak 2016;26(8):658-61.

25. Gong YX, Cui SN, Li L, Wang MM, Guo N. [Diagnostic value of human neutrophil peptide in spontaneous bacterial peritonitis]. Zhonghua Gan Zang Bing Za Zhi 2013;21(12):944-8.

26. Determann RM, Achouiti AA, El Solh AA, Bresser P, Vijfhuizen J, Spronk PE, et al. Infectious pleural effusions can be identified by sTREM-1 levels. Respir Med 2010;104(2):310e5. [CrossRef] 